https://doi.org/10.48009/2_iis_2005_147-153

\title{
ACHIEVING COMPETITIVENESS BY ORGANIZATIONAL LEARNING: STRATEGY, TRANSFORMATION AND MEASUREMENT
}

\author{
Zong Dai, Alfred University, daiz@alfred.edu \\ Frank Duserick, Alfred University, fduserick@alfred.edu \\ Li Dai, University of Toronto, li.dai@utoronto.ca
}

\begin{abstract}
This paper is a case study of achieving competitive advantage by organizational learning. It examines the process of a leading IT corporation (Unisys) transforming itself into a learning organization. The research methodology employs a fact-based principle that combines quantitative and qualitative methods. Data was collected and analyzed at corporate level of the subject organization. A model of strategic transformation by organizational learning has been developed based on the findings.
\end{abstract}

Keywords: Organizational learning, knowledge, skills, competitive advantage, performance

\section{INTRODUCTION}

There has been a dramatic increase in interest and documentation in the learning organization since the early 1990s. The existing literature falls readily into two categories: popular works directed to managers, and academic works designed to make a more theoretical contribution. However, the literature lacks empirical studies in business repositioning and/or organizational transformation through organizational learning [e.g., 2, 6, 9, 10, 14, 15]. This paper is a case study of business repositioning and transformation through organizational learning.

A leading IT services company (Unisys Corporation) is selected for this study. Data collection has been conducted through the company's website, interviews and documentation such as annual reports, archival records, financial reports, electronic databases, and other publications. President Mary Shacklett of Transworld Data was interviewed with focused topics. Transworld Data was Unisys' partner involved in establishing Unisys University.

The corporate performance literature has documented two market-oriented outcome measures of intellectual assets: Tobin's q and market value added (MVA) [e.g. 3, 4, 5, 7, 8, 21, 23]. Tobin's q is the ratio of market value of the firm (share price times number of shares) to the replacement cost of its assets. A q value greater than one means that the market believes the assets can generate cash flows that exceed the liquidation value of those assets [22]. The Tobin's q has been used to explain a wide variety of phenomena, particularly the value of intangible assets [e.g., 7, $11,13,16,17,18,19,20,24]$. MVA is the result of the firm's market value minus its book value. A positive MVA indicates an increase in shareholder wealth, while a negative MVA means a decrease in shareholder wealth.

This study combines quantitative and qualitative approaches to the analysis of data. The quantitative outcome measures used in this study are Tobin's q and MVA and well-recognized business rankings as the proxies of qualitative measurement. 


\section{COMPANY OVERVIEW}

Headquartered at Blue Bell in Pennsylvania, USA, Unisys is a worldwide information technology services and solutions company with more than 36,000 employees and operates in more than 100 countries around the world.

In 1986, as the second largest computer firm in the nation, Unisys stepped up diversification of its product line. Since the mid-1990s Unisys began to shift to service and continued its restructuring. By 1999 the service operations generated 70 percent of the company's revenue.

There were two significant challenges that Unisys faced. The first was the move to a more diversified computing platform that combined client/server platform. The second revolved around the many Unisys' clients who were seeking web-enabled applications.

Because new technologies emerge every few months, it is a daunting challenge and important task to keep staff well trained. This meant that Unisys had to help its employees learn new skills, transforming their skill sets from traditional technology-based knowledge to focus on skills that would be required for increasingly complex networking, outsourcing, security and systems integration engagements.

\section{UNISYS UNIVERSITY}

Unisys top management identified continuous learning as a key driver of its business strategy and defined the goal of creating a centralized training solution. CEO Larry Weinbach called for the establishment of Unisys University and led the initiative in 1999 that would provide continuous learning to more than 36,000 Unisys employees in more than 100 countries.

Unisys University has established a physical campus in each of the five geographical locations where Unisys has the largest presence: North America, Europe, the UK, Latin America, Asia and the South Pacific. There are 10 schools within Unisys University: Leadership, E-Business, Business, Human Resource/Legal, Services, Technology, Marketing, Project Management, Finance, and Sales. The University brought 120 training staff under one umbrella and defined 400 roles (adjusted from previous 6,000 roles) for Unisys' worldwide staff. For most roles the university defined a specific training path and redesigned curriculum consisting of 1,700 courses, adjusted from the previous 3,000 to eliminate duplication and cut costs.

Unisys University combines elements of classroom, mentored and modularized e-learning. To better facilitate the learning process, Unisys University has developed the approach of training configurations that allows students and their mentors to configure the appropriate sequences of modularized courses.

The business repositioning and the establishment of Unisys University have greatly strengthened Unisys' competitiveness in a challenging economic environment. For instance, during 2001 (the worst economic downturn in the past 20 years), Unisys delivered profits for every quarter. 


\section{PERFORMANCE SCORECARD}

For a technology-based services and products company like Unisys, creating its own university and close alliances with research universities and IT business partners would have a significant bearing on its corporate performance. In the case of Unisys, we can see a clear strategic cascade. That is, competitive forces and business strategy drive the organizational learning which strategically improve the corporate performance. Table 1 summarizes the business initiatives that drive the implementation of Unisys University.

Table 1. Unisys Corporation Business and IT Interactions

\begin{tabular}{|c|c|c|}
\hline Period & Business Initiative & Unisys University Initiative \\
\hline $1980 ’ s$ & $\begin{array}{l}\text { - Diversification of products by moving into } \\
\text { small and mid-sized computers }\end{array}$ & $\begin{array}{l}\text { - Initiate Unisys University in } \\
1999\end{array}$ \\
\hline $1990 ’ s$ & $\begin{array}{l}\text { - Transition from hardware manufacturer to the } \\
\text { provider of full range of IT services } \\
\text { - Moved out computer manufacturing in } 1998\end{array}$ & $\begin{array}{l}\text { - Establish physical campuses in } \\
\text { each of the five geographical } \\
\text { locations: North America, }\end{array}$ \\
\hline Since & - International acquisitions & Europe, UK, Latin America, \\
\hline 2000 & - Provide IT outsourcing business to large & Asia and the south Pacific \\
\hline
\end{tabular}

In short, knowledge-and-skill-intensive IT services and Unisys University would be a major driver for Unisys corporate performance since the mid-1990s. To examine Unisys corporate performance for this transformational period, Tobin's q and MVA for the years of 1993-2002 were calculated and reviewed (along with typical business rankings for the company displayed as a supplementary qualitative measurement). The results are displayed in Table 2.

Table 2. Tobin's q of Unisys Corporation (1993-2002)

\begin{tabular}{ccccccccccc}
$\mathbf{1 9 9 3}$ & $\mathbf{1 9 9 4}$ & $\mathbf{1 9 9 5}$ & $\mathbf{1 9 9 6}$ & $\mathbf{1 9 9 7}$ & $\mathbf{1 9 9 8}$ & $\mathbf{1 9 9 9}$ & $\mathbf{2 0 0 0}$ & $\mathbf{2 0 0 1}$ & $\mathbf{2 0 0 2}$ & Mean \\
\hline 1.9114 & 1.4258 & 3.2692 & 6.3846 & 2.8707 & 5.7838 & 5.0783 & 2.1099 & 1.9028 & 3.7727 & 3.4509
\end{tabular}

Note: Tobin's q is calculated by the formula of q=Market Value/(Total Assets-Total Liabilities), based on the data of Unisys Corporation Annual Reports (1993-2002), Unisys Corporation Worldscope 10-K History (1993-2002), Disclosure Inc. 1996.

As shown in Table 2, Tobin's q of Unisys is well above one for each of the ten years, with a mean of 3.4509 for the ten years. Very notably, the q value jumped up from 3.2692 of 1995 to 6.3846 of 1996 when Unisys began to significantly shift to IT service businesses; it remained above 5 for the years of 1998 and 1999 when Unisys began to transform itself into a learning organization. This represents the financial market's strong reaction to the Unisys' transformation of hardware-based provider into a knowledge-and-skill-intensive services provider and learning organization.

However, the q value fell from 5.0783 for the year 1999 to 2.1099 and 1.9029 for 2000 and 2001, respectively, as a market reaction to the sharp contraction in 2000 and 2001 in the IT industry after more than a decade of robust growth. While industry conditions remained tough in the systems integration and consulting market, Unisys was seeing encouraging signs of progress 
from its efforts to reposition this business. Indeed, its Tobin's q went up from 1.9028 in 2001 to 3.7727 in 2002.

During an eight-year period from 1995 to 2002, Unisys' performance earned a mean q value of 3.8965 , which was higher than the ten-year mean of 3.4509, though there was the unprecedented industry downturn during the 2000-2001 period. This shows us that Unisys' repositioning of knowledge-and-skill-intensive IT service and organizational learning initiative was successfully recognized by the financial market. It should be emphasized that Unisys' financial statements included a significant item of Intangible Assets in the Assets category, and the value of Intangible Assets has been included in the formula for calculating Tobin's q. This means that there must be significant value of unrecognized nontraditional intangible assets embedded and hidden in the firm but detected by the market mechanism.

It could be inferred that unrecognized intangible assets embedded in its major business segment contributed to the significant $q$ value above one. Those unrecognized intangible assets include the IT personnel skills, because the knowledge-and-skill-intensive IT services are Unisys's major business segment since the mid-1990s, supported by its organizational learning initiatives. In this case, organizational learning is a critical factor for Unisys' core competency for offering a full range of IT services to its customers in the very competitive markets. Otherwise, it would be difficult to imagine that Unisys could remain a leader in the highly competitive business for the last eight years. This statement is also supplemented by the following complementary measures of MVA and typical business rankings including top IT innovator rankings for Unisys during the period. As the Table 3 shows, Unisys has had significant positive MVA for each of ten years with a mean of 1.2485 billion dollars.

Table 3. Market Value Added (MVA) of Unisys Corporation (1993-2002, in 000's)

\begin{tabular}{ccccccccccc}
$\mathbf{1 9 9 3}$ & $\mathbf{1 9 9 4}$ & $\mathbf{1 9 9 5}$ & $\mathbf{1 9 9 6}$ & $\mathbf{1 9 9 7}$ & $\mathbf{1 9 9 8}$ & $\mathbf{1 9 9 9}$ & $\mathbf{2 0 0 0}$ & $\mathbf{2 0 0 1}$ & $\mathbf{2 0 0 2}$ & Mean \\
\hline 1125300 & 1034200 & 289900 & 185800 & 1205900 & 1535600 & 1953300 & 2186100 & 2112700 & 856000 & 1248480
\end{tabular}

Note: Market Value Added (MVA) is calculated by the formula of MVA=Market Value-Book Value, which as accounting book value of a firm, is found by subtracting total liabilities from its total assets, based on the data of Unisys Corporation Annual Reports (1993-2002), Unisys Corporation Worldscope 10-K History (1993-2002), Disclosure Inc. 1996.

Table 4 illustrates selected business rankings as the proxies of qualitative measurement for Unisys corporate performance in the period of 1993-2002, adapted from the databases of Business \& Company Resource Center at Alfred University [1].

Table 4. Selected Business Rankings for Unisys Corporate Performance

\begin{tabular}{|c|c|c|c|c|c|c|c|c|c|}
\hline Rankings & 1994 & 1995 & 1996 & 1997 & 1998 & 1999 & 2000 & 2001 & 2002 \\
\hline Largest U.S. Corporations by Revenue & 158 & 203 & 226 & 244 & & 226 & & & \\
\hline $\begin{array}{l}\text { Leading Information Technology } \\
\text { Innovators }\end{array}$ & 131 & 22 & 70 & 62 & & 127 & & & 260 \\
\hline $\begin{array}{l}\text { Top information technology service } \\
\text { providers }\end{array}$ & & & & 9 & & & & & \\
\hline $\begin{array}{l}\text { Software Companies Spending the Most } \\
\text { on R\&D }\end{array}$ & & & & 6 & & & & & \\
\hline
\end{tabular}


U.S. Corporations with the Highest One-

Year Return to Investors

Companies with the Greatest Return to

Investors

Corporations with the Highest Share-Price

Gain

Most Admired Computer and Data

Services Corporations

Top Computer Hardware Companies

Top Computer Software/Services

Companies by Segment Revenue

Top Manufacturers of Mainframe

Computers

World's Largest Manufacturing

Companies by Three-Year Return on

Equity, 1998-2001

Companies that delivered the Most for

Investors Based on the 500 Largest

Companies in Terms of Revenue

Top Companies by Return on Equity

Top U.S. Computer and Peripherals

Companies by Earnings

Top U.S. Computer and Peripherals

Companies by Revenue

Largest Business Service Companies by

Sales

Top Computer and Data Services

Companies in the Fortune 1,000

Top Computer Hardware Contractors for the Government

Top Computer Services and Software

Contractors for the Government

Top GWAC Contractors in Scientific and

Engineering Workstations

Top GWAC Contractors in IT Overall

World's Largest Software and Services

Suppliers

Largest Computer and Peripherals

Companies by Revenue

Most Profitable Computer and Peripherals

Companies

Top Fortune 1,000 Companies in

Computer and Data Services
10

2

10

8

\section{9}

6

$7 \quad 5$

9

10

2

5

CONCLUSION

The Unisys case exemplifies that in order to successfully compete in an increasingly changing business and technological environment, a firm can be successful by managing change through organizational learning.

A model of strategic cascade of organizational learning is developed to depict Unisys' approach to a strategic organizational transformation. It is a five-step-and-iterative process. 
First, a firm facing challenges needs a vision of how it will be in the future, as Unisys envisioned in the early 1990s to transform itself into a services-led, technology-enable IT solution provider. Second, a strategic management "loop" (1, 2 or 3 step) is needed to decide on a transformation strategy, complete a strategic plan and develop tactical action plans. In the case of Unisys, a centralized organization-wide learning solution was a strategic differentiator. The third step is to launch organizational learning to build competence, as Unisys did. The fourth step is to implement the transformation strategy; for instance, Unisys implemented Unisys University and the learning alliance. The fifth step is to monitor and review the desired outcomes of the implementation of the transformation strategy and decide if there is a need to continue, modify or change (iteration looping) based on performance. In the case of Unisys, its transformation has been successful so far.

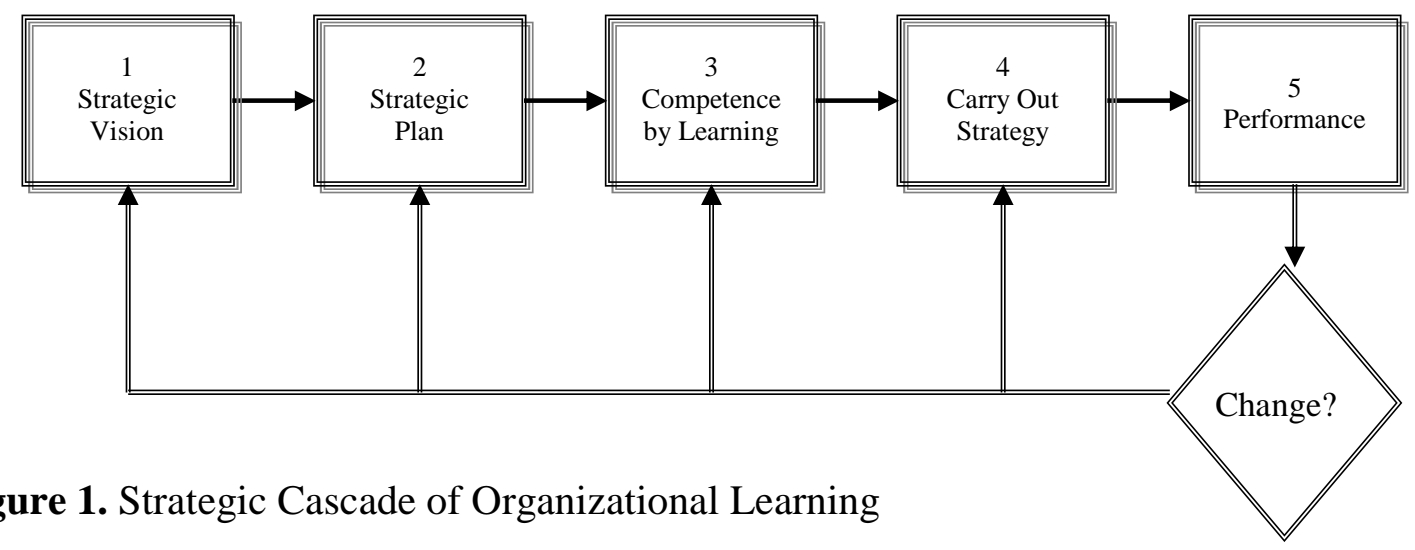

A business repositioning and/or organizational transformation through learning would be much less painful than an ordinary organizational changing process because of no resistance to change, and would be more likely successful. What the Unisys case has ultimately enlightened is what Hame and Heene [12] abstractly addressed; that is, that the process of renewal rather than the source itself is considered to be the ultimate source of competitive advantage. Specifically, at Unisys, the process of knowledge learning and creation rather than knowledge itself is evidenced to be the source of competitive advantage. A strong learning capability like a wellspring injects fresh competence flow into the pool of corporate competence.

\section{REFERENCES}

1. Alfred University (2005). Business \& Company Resource Center, Alfred University, New York, 14802.

2. Argyris, C. \& Schon, D.A. (1996), Organizational Learning II: Theory, Method, and Practice, Addison-Wesley, Reading, MA.

3. Bharadwaj, A. (March 2000). A Resource-Based Perspective on Information Technology Capability and Firm Performance: An Empirical Investigation. MIS Quarterly, 169-197.

4. Bharadwaj, A., Bharadwaj, S. G., \& Konsynski, B. R. (1999). Information Technology Effects on Firm Performance as Measured by Tobin's q. Management Science, 45(6), 10081024.

5. Bosworth, D. \& Rogers M. (Dec 2001). Market Value, R\&D and Intellectual Property: An Empirical Analysis of Large Australian Firms. Economic Record, 323-337. 
6. Dale, M. (1994). Learning organizations, in Mebey, C. \& Iles, P. (Eds), Managing Learning, Routledge, London: The Open University.

7. Dzinkowski, R. (Feb 2000). The Measurement and Management of Intellectual Capital: An Introduction. Management Accounting, 32-36.

8. Ellinger. A. D., Ellinger, A. E., Yang, B., \& Howton, S. W. (Spring 2002). The Relationship between the Learning Organization Concept and Firms' Financial Performance: An Empirical Assessment. Human Resource Development Quarterly, 5-21.

9. Fioi, C.M. \& Syles, M.A. (1995). Organizational Learning, Academy of Management Review, 10(4), 803-13.

10. Garvin, D. (1993). Building and learning organization, Harvard Business Review, 71(4), 7891.

11. Hall, B. H. (1993). The Stock Market's Valuation of R\&D Investment During the 1980s. AEA Papers and Proceedings, 70(2), 259-264.

12. Hamel, G. \& Heene, A. (1994). Eds, Competence-based Competition, New York, NY:Wiley.

13. Hirschey, M. (1982). Intangible Capital Aspects of Advertising and R\&D Expenditures. Journal of Industrial Economics, 30(June), 375-290.

14. Huber, G. (1989). Organizational learning; an examination of the contributing processes and a review of the literature, prepared for the NSF Sponsored conference on Organizational Learning, Carnegie Mello University, May, 18-20.

15. Jones, A. \& Hendry, C. (1992). The Learning Organization; A Review of the Literature \& Practice, Coventry, UK: Warwick Business School, University of Warwick.

16. Lang, L. H. P., Stulz, R. M. (1994). Tobin's q, Corporate Diversification \& Firm Performance. Journal of Political Economy, 102, 1248-1280.

17. Megna, P. \& Klock, M. (1993). The Impact of Intangible Capital on Tobin's q in the Semiconductor Industry. AEA Proceedings Paper, 83, 265-269.

18. Salinger, M. A. (1984). Tobin's q, Unionization, \& the Concentration-Profits Relationship. $R \&$ Journal of Economics, 15 (Summer), 159-170.

19. Simon, C. J. \& Sullivan, M. W. (1993). The Measurement \& Determinants of Br\& Equity: A Financial Approach. Marketing Science, 12(Winter), 28-52.

20. Smirlock, M., Gilligan, T., \& Marshall, W. (1984). Tobin's q \& the Structure-Performance Relationship. American Economic Review, 74(December), 1051-1060.

21. Thaker, K. (2002). Financial Management Analysis of Knowledge Capital \& Earning with Reference to Selected Companies in India. Journal of Financial Management \& Analysis, Jul-Dec, 67-82.

22. Tobin, J. \& Brainard, W. C. (1968). Pitfalls in Financial Model Building, American Economic Review, LVIII(2), 99-122.

23. Watkins, K. E., Yang, B., \& Marsick, V. J. (1997). Measuring Dimensions of the Learning Organization. In Proceedings of the Academy of Human Resource Development Conference, Atlanta: Academy of Human Resource Development, 543-546.

24. Wernerfelt, B. \& Montgomery, C. A. (1988). Tobin's q \& the Importance of Focus in Firm Performance. American Economic Review, 78(March), 246-250. 